\title{
Bullying behavior and its relationship to children's self-esteem
}

\author{
Azlin Atika Putri ${ }^{1}$, Yesi Novitasari ${ }^{2}$, Siti Fadillah ${ }^{3^{*}}$ \\ 1,2,3 Department of Early Childhood Education, Universitas Lancang Kuning, Indonesia \\ ${ }^{*}$ corresponding author
}

$\begin{array}{ccc}\text { First received: } & \text { Revised: } & \text { Final Accepted: } \\ 30 \text { November 2021 } & \text { 13 December 2021 } & 30 \text { December 2021 }\end{array}$

\begin{abstract}
This study aims to determine whether bullying behavior influences children's self-esteem aged 5-6 years in Mutiara Cendekia Early Childhood Education (ECE) in Pekanbaru, Indonesia. This research is quantitative using the simple linear regression formula. The sampling technique used is total sampling. The results showed that bullying behavior is significantly related to the children's self-esteem. It also indicated that children aged 5-6 years who play online games have high self-esteem. While the remaining $43.6 \%$ is influenced by other factors not examined. These findings should be a concern to parents and teachers to control the use of online games for children.
\end{abstract}

Keywords: Bullying Behaviour, Online Media, Self Esteem

${ }^{1}$ Corresponding Author:

Affiliation: Department of Early Childhood Education,

Universitas Lancang Kuning, Indonesia

Email: azlin@unilak.ac.id 


\section{INTRODUCTION}

Bullying behavior in children aged 5-6 years is now widely seen in schools. Children unknowingly bully their friends because at first, they were just joking, they simply called their friends fat, curvy, stupid, or other negative names, so that friends who are called negative names will be angry or cry (Mahriza et al., 2020). Then, bullying behavior is often the cause of a child not wanting to go to school. When it's time for school they will have a tantrum or have lots of reasons for not going to school such as stomach pain, dizziness, or not feeling well. However, after being investigated by his parents, it turned out that the child did not want to go to school because of the bullying behavior he had received at school. There is also a type of child who has a grudge against his friend's bullying treatment when there is an opportunity to avenge his friend's treatment, the child will repay his friend's bullying with a punch when his friend is careless or has forgotten the previous incident, resulting in fights and blaming each other.

Based on the phenomenon in the field, it shows that the majority of parents at Early Childhood Education of Mutiara Cendekia Pekanbaru have given gadgets to their children aged 5-6 years. Even they are proud of their children can play online games and sit down. The phenomenon of playing online games by children has entered an alarming level because of their behavior that imitates the actions that exist in these online games such as kicking friends, hitting, mocking, threatening, and talking dirty to friends and teachers as well excessive emotions. The above phenomenon is in line with the opinion expressed by the UI Psychology expert Prof. Dr. Fawzia Aswin Hadis, the worst impact of violent video games is their tendency to imitate (Putri dan Trisna, 2013). Furthermore, the facilities which are provided by parents without any control result in children having no restrictions and rules in playing these online games. One of the games that are mostly played by children is the free fire game. Online games such as free fire games should be games intended for adults, but this phenomenon in the field of game free fire has also been played by children aged 5-6 years.

This free fire game is played by 20 children. Players are required to kill many people who are enemies in the game so that players can advance to a higher level or a higher rank. Even to get prizes, players often have to complete given missions, such as shooting barrels filled with flammable and explosive liquids when shot or blowing up cars if no enemies are blocking them. Indirectly, playing this free fire game teaches children that the enemy must be killed and making damage is a natural behavior, so acts of violence are normal. Violence is a common thing for children aged 5-6 years who play free fire games such as hitting or bullying friends who lose in playing free fire games. The use of online media such as free fire games has an impact on bullying behavior in children aged 5-6 years, this is in line with the results of research conducted by Paul. JC Adachi and Teena entitled "The effect of video games competition and violence on aggressive behavior" was conducted in 2011 in Canada. The study found that violence in video games has a direct effect on children's violent behavior (Adachi \& Willoughby, 2011). The intended behavior can be in the form of acts of violence, both physical and non-physical, such as hitting and verbal abuse such as bullying behavior. In Indonesia, what is even more worrying is that game free fire which is supported by the government by holding a game free fire tournament to compete for the presidential trophy. 
The definition of bullying itself according to the National Commission for Child Protection is long-term physical and psychological violence perpetrated by a person or group against someone unable to defend them. Bullying is carried out in situations where there is a desire to hurt, frighten or make others depressed, depressed, and helpless. While bullying according to (Wahidin, 2017)bullying is aggressive behavior that is intended to harm or make individuals feel difficult, occurs repeatedly from time to time, and takes place in a relationship where there is no balance of power or power in it.

According to (Maria \& Novianti, 2016) bullying behavior is an act that is done to hurt other people, these actions are in form of expressing hurtful things, making fun or calling names with painful calls, ignoring or ostracizing from the game group, hitting, kicking, encouraging, threaten, spread gossip and spread statements to hurt the victim. Bullying is also said to be an action taken by someone to another person to hurt that person and is carried out repeatedly from time to time, where the injured party is called the victim. Bullying behavior is bullying behavior either physically or psychologically that is done intentionally by a person or group against another person or group to hurt and is carried out continuously in the form of bad calls, making fun of even physical bullying such as bullying, punching, kicking, isolating and so on, to make other people feel depressed, depressed and helpless (McLeod, 2007).

Kaplan and Haenlein created a classification scheme for various types of social media in the Journal of Politicom Indonesiana, (Kaplan \& Haenlein, 2012). According to Kaplan and Haenlein, there are six types of social media, namely: Collaborative Projects, namely a social media that can create content and in its manufacture can be accessed by a global audience. There are two sub-categories included in the collaborative project in social media, namely (1) Wiki: Wiki is a site that allows users to add, delete and change text-based content, for example, Wikipedia, Wiki Ubuntu-ID, Wakakapedia, and others. (2) Social Bookmarking Applications: Social bookmarking applications, which allow group-based collection and rating of internet links or media content. Examples: Social Bookmarks: Del.icio.us, StumbleUpon, Digg, Reddit, Technorati, Lintas News, Infogue Writing: Cerpenista, then.com, Reviews Amazon, GoodReads, Yelp. (3) Blogs and microblogs (Blogs and Microblogs) Blogs and microblogs are applications that can help users to keep posting about any statement until someone understands. A blog itself is a website that conveys about an author or group of writers, whether it is an opinion, experience, or daily activity. Example: Blogspot (Blogger), WordPress, Multiply, LiveJournal, Blogsome, Dagdigdug, and others. Microblog: Twitter, Tumblr, Posterous, Koprol, Plurk, and others. Forum: kaskus, Warez-bb, indowebster.web.id, forumdetik Q/A (Question/Answer): Yahoo!, Answer, TanyaLinux, Formspring.(4) Content: Content communities or community content is an application that aims to share with someone both remotely and close, sharing such as videos, ebooks, images, and others. Example: Image and Photo Sharing: Flickr, Photobucket, DeviantArt, and others. Video-Sharing: YouTube, Vimeo, Mediafire, and others. Audio and Music Sharing: Imeem, Last.FM, Share music, Multiply. File Sharing and Hosting: 4shared, Rapidshare, Indowebster.com, design: Treadless, ChangeBaju, KDRI (Ministry of Design of the Republic of Indonesia). (5) Social networking sites (Social Networking Sites): Social networking sites are sites that can help someone to create a profile and then be able to connect with other users. Social networking sites are applications that allow users to connect using their profiles or personal accounts. Example: Friendster, 
Facebook, LinkedIn, Foursquare, MySpace, and others. (6) Virtual game worlds: Virtual worlds where 3D environment replicates, where users can appear in the form of desired avatars and interact with other people as in the real world, such as online games, for example, Travian, Three kingdoms, Second Life, e-Republik, World of Warcraft, Free Fire, Mobile Legend and others. (7) Virtual Social Worlds: Virtual Social Worlds is an application that simulates real-life through the internet. Virtual Social Worlds is a site that allows users to interact in a three-dimensional platform using avatars that are similar to real life. Example: Map: Wikimapia, GoogleEarth, e-commerce: eBay, Alibaba, juale.com, and others.

According to (Santrock, 2011)self-esteem or self-esteem is the overall view of the individual about himself. Self-esteem is also sometimes called self-worth or self-image. For example, a child who has high self-esteem does not only see himself as a person but also as a good person. Self-esteem is a person's judgment or feelings about himself. Self-confidence is one of the important aspects in the formation of a positive self-concept. (Santrock, 2003).

Meanwhile, according to (Noordjanah, 2013)self-esteem is an assessment made by an individual of himself related to the individual himself, the assessment usually reflects acceptance or rejection of himself and shows how far the individual believes that he can succeed, feels important., and feel valuable. At this time, a person will recognize and develop all aspects to determine whether he will have positive or negative self-esteem.

McLeod (2007) noted two versions of the need for self-esteem, namely positive and negative. Positive self-esteem will generate self-confidence, self-esteem, self-confidence, a sense of usefulness, and a sense that their presence is needed in this world. In contrast to negative self-esteem, they view themselves negatively, feel worthless, useless in any way, this makes children unable to establish relationships with friends, so children are easily angry and offended, and will easily hurt others. Group norms can also make bullying behavior appear which in turn makes the behavior develop, (Hunter et al., 2014).

Self-esteem is a person's judgment or feelings about his or her self-worth. If a person feels his self-esteem is high he will feel needed by the people around him and be able to overcome everything he faces, but on the contrary, if a person's self-esteem is low then he will feel unneeded by his surroundings so that he becomes an angry person because he does not know how to solve the problem properly.

\section{METHOD}

The type of research used in this research is descriptive quantitative using a simple linear regression formula. According to quantitative research methods, that is a process using data in the form of numbers as a tool to find information about what you want to know. Quantitative research methods can be defined as research methods based on the philosophy of positivism, used to examine certain populations and samples, data collection using research instruments, quantitative/statistical data analysis to test predetermined hypotheses. This study uses a descriptive approach to describe the object of research or research results. The definition of descriptive according to (Sugiyono, 2015)is a method that serves to describe or describe the object under study through data or samples that have been collected as they are without analyzing and making generally accepted conclusions. This research can also be called quantitative descriptive research with a simple linear 
regression formula, used to determine the percentage of the contribution of the influence of the independent variables simultaneously on the dependent variable because in this quantitative formula the percentage of numbers is used which is then analyzed from the results of the calculation of these numbers. This study consisted of the independent variable, namely bullying $(X)$, and the dependent variable, namely self-esteem $(Y)$. The relationship between variables can be seen in the following figure:

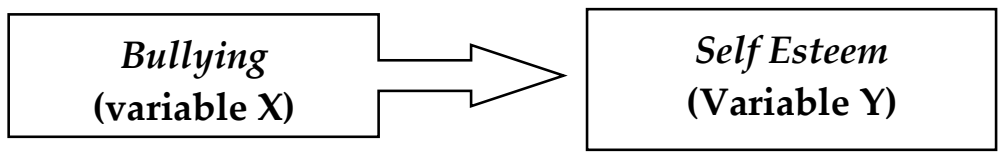

Figure 1. Relationship between Variable $\mathrm{X}$ and Variable $\mathrm{Y}$

The population in this study were children of the Early Childhood Education of Mutiara Cendekia Pekanbaru aged 5-6 years which consisted of 20 children. The sampling technique in this study is to use a total sampling technique. According to Sugiyono (2007), the total population is less than 100, the entire population is used as a research sample. Total sampling is a sampling method where the number of samples is the same as the population. The reason for choosing total sampling was because the population that the researchers took was less than 100, so the whole sample was used as a research sample, namely 20 children aged 5-6 years in Early Childhood Education of Mutiara Cendekia Pekanbaru. The data collection techniques are observation and questionnaires (questionnaire).

\section{FINDINGS}

In the results of previous studies, researchers distributed questionnaires to test whether the statement items were valid or not, and tested the reliability to see if the data was classified as very reliable or not. In this case, the test questionnaire statement was distributed to 20 parents/guardians at Early Childhood Education of Mutiara Cendekia Pekanbaru, where the questionnaire given to parents/guardians consisted of 14 statement items about bullying inspired by online media such as making fun of behavior. Ridicule, exclusion from the game group, hitting, kicking, pushing, threatening, and spreading gossip to hurt the victim. The results of the valid and reliable test can be seen as follows. 


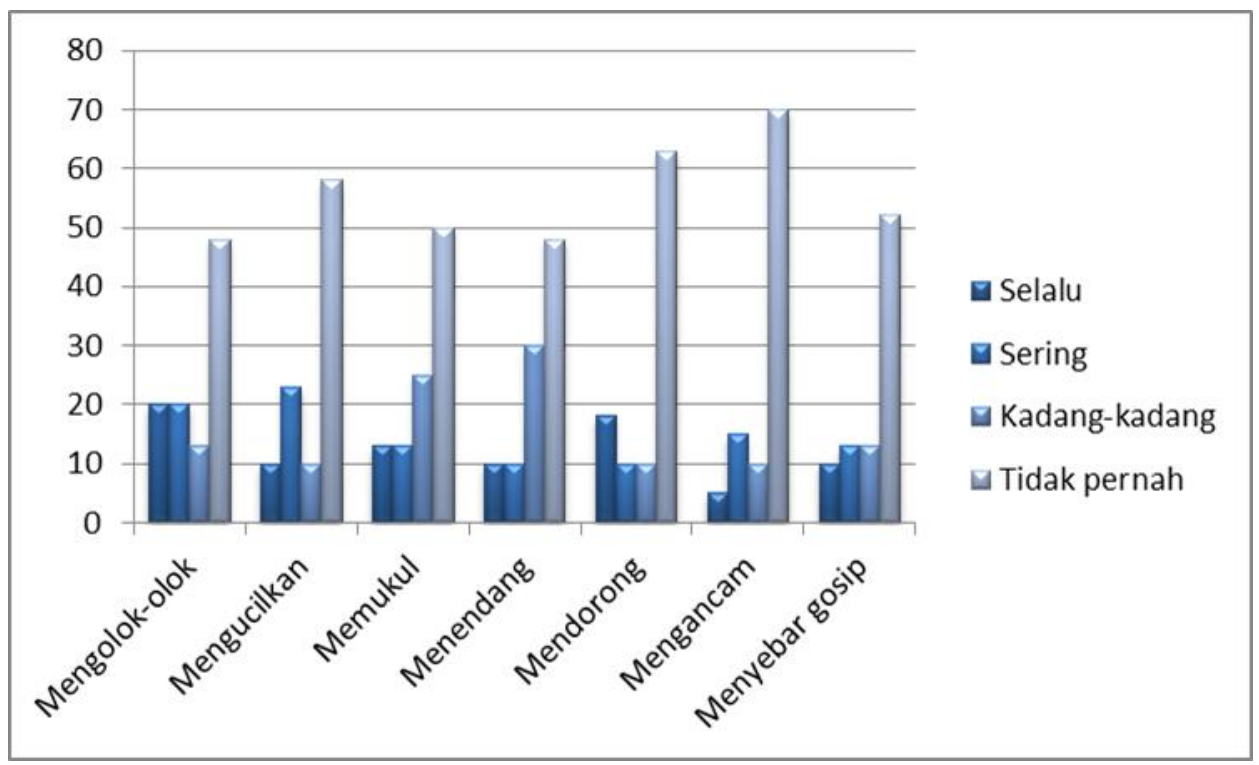

Diagram 1. Online Media Inspired Bullying Score

In the results of previous studies, researchers distributed questionnaires to test whether the statement items were valid or not, and tested the reliability to see if the data was classified as very reliable or not. In this case, the test statement of the questionnaire was distributed to the parents/guardians of 20 students at Early Childhood Education of Mutiara Cendekia Pekanbaru, where the questionnaire given to the parents/guardians of students consisted of 10 statement items regarding the self-esteem of children aged 5-6 years such as behavior that reflects an attitude of self-confidence, self-esteem, selfconfidence, a sense of usefulness, a sense that their presence is needed in the world. The results of the valid and reliable test can be seen as follows.

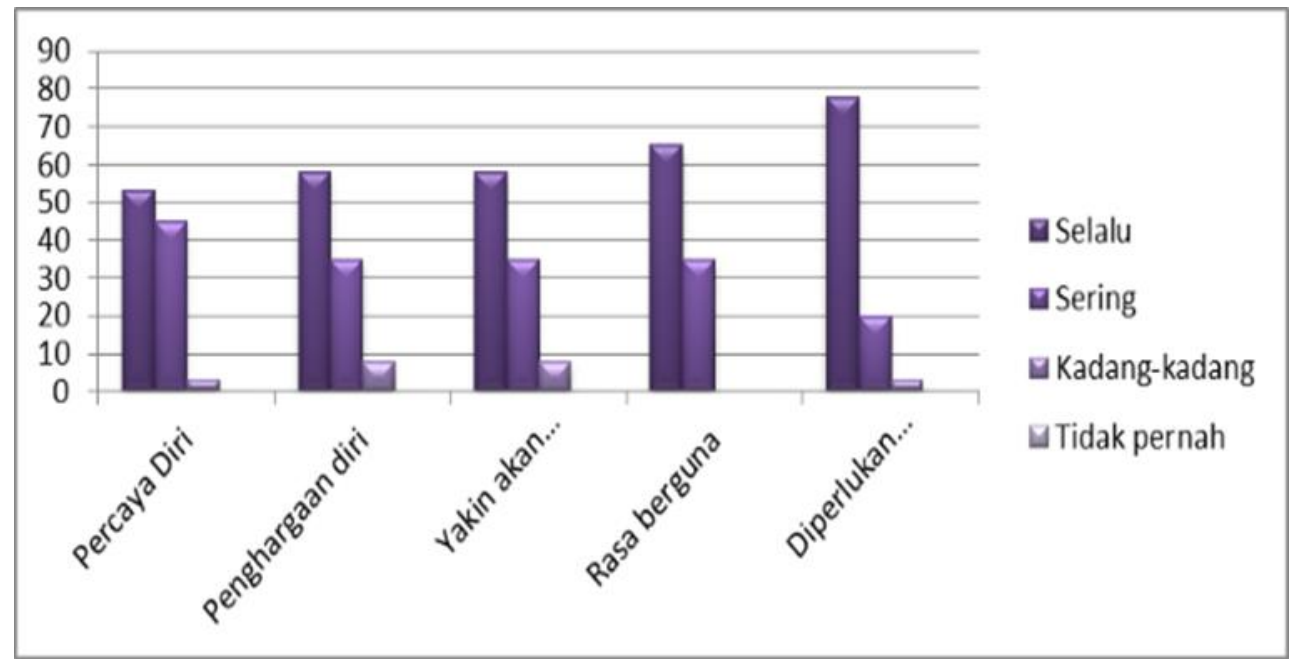

Diagram 2. Self Esteem Score for Children aged 5-6 Years

\section{DISCUSSION}


The results of this study are following the theory put forward by Hasan and Ee (2015) who argue that bullying behavior is an action taken to hurt others, the action is in the form of expressing painful things, making fun of or calling names with painful calls, ignoring or excluding from the game group, hitting, kicking, pushing, threatening, spreading gossip and spreading statements to hurt the victim. This is under the research results shown in Figure 4 regarding the threatening aspect of $70 \%$.

The National Commission for Child Protection also defines bullying as long-term physical and psychological violence perpetrated by a person or group against someone unable to defend them. Bullying is carried out in situations where there is a desire to hurt, frighten or make others depressed, depressed, and helpless. This is in line with the opinion (Monks \& Smith, 2006)which states that bullying is aggressive behavior that is intended to harm or make individuals feel distressed, occurs repeatedly from time to time, and takes place in a relationship where there is no balance of power or power in it.

Bullying can be reduced through education from parents from home. Every parent who has early childhood has different experiences in dealing with the problems of their children (Prabowo et al., 2020). But apart from that, preparing a strategy for educating children with good moral values is a very appropriate parent investment strategy (Wahyuni \& Nuraini, 2019). A child with low character quality is a child whose level of emotional-social development is also low. As a result, children are at great risk of experiencing difficulties in learning, interacting socially, and being unable to control themselves (Sutriyanti, 2016). Developing character is more closely related to the optimization of the right-brain function. Do not let parents teach character education and religion, it turns out that in practice it places more emphasis on aspects of the left brain in the form of rote memorization, whereas character building must be carried out systematically and continuously involving aspects of knowledge, feeling, loving and acting. (Rahim, 2013)the habits that parents can develop in the family towards early childhood can refer to the following nine characters: 1 ) love of God and the universe and its contents, 2) responsibility, discipline, and independence, 3) honesty, trustworthiness, diplomatic, 4) respect and courtesy, 5) compassion, generosity, care, and cooperation, 6) self-confidence, creative, hard work, and never give up, 7) justice and leadership, 8) kind and humble, 9) tolerance, love of peace, and unity.

Happiness is also a determining factor in children's bullying behavior and their dependence on social media is a trigger for imitation of bullying behavior. According to (Arbiyah et al., 2007): "Such as joy, joy or happiness, affection, and pride or gratitude are factors that increase positive affect from within individuals such as optimistic looking at the future". Furthermore (Ariati \& Hyoscyamina, 2017), "People who are optimistic about the future feel happier and satisfied with their lives. Individuals who positively evaluate themselves will have good control over their lives, so they have positive dreams and hopes about the future. Based on this opinion, it is necessary to increase the child's optimism in seeing his future to suppress his desire to carry out bullying behavior.

According to (Chakrawati, 2015) in a journal entitled "The Relationship Between Bullying and the Learning Achievement of Children Victims of Bullying at the Elementary School Level" There is a negative relationship between bullying and the learning achievement of children who are victims of bullying. Children who are victims of bullying will have difficulty getting along, feel afraid to come to school so that their absenteeism is 
high and they miss lessons and have difficulty concentrating in following lessons so that which has an impact on their learning achievement. Meanwhile, $43.6 \%$ of bullying behavior is influenced by other factors not studied such as parenting style by their parents as the results of the research revealed by (Maria \& Novianti, 2016), which shows that parenting has a positive effect on self-esteem (self-esteem) and parenting has a direct positive effect on bullying behavior. In the formation of self-esteem in children, the environment becomes a very important factor, namely, the family environment, the community environment, and the school environment. The role of parents from the family environment, peers, community, and the role of teachers from the school environment are the main supporters in the process of fulfilling self-esteem (Hunter et al., 2014).

\section{CONCLUSION}

The effect of bullying behavior inspired by online media at school on the self-esteem of children aged 5-6 years at Early Childhood Education of Mutiara Cendekia Pekanbaru has a significant effect on children's self-esteem as indicated by a probability value of 0.001 $<0.05$. Based on the SPSS output, it appears that $68.4 \%$ of bullying is influenced by the Self Esteem variable, which means that self-esteem children aged 5-6 years who play online games have high self-esteem. While the remaining $43.6 \%$ is influenced by other factors not examined. This should be a concern for parents and adults around children aged 5-6 years to provide control over the use of online games for children aged 5-6 years. The novelty in this study is that there is a change in the pattern of bullying in children who switch from bullying behavior that is influenced by parenting, environment, and others. However, based on the results of this study, bullying in children also occurs due to technological advances in the form of online games that children play through gadgets.

\section{REFERENCE}

Adachi, P. J. C., \& Willoughby, T. (2011). The effect of video game competition and violence on aggressive behavior: Which characteristic has the greatest influence? Psychology of Violence, 1(4), 259-274. https://doi.org/10.1037/a0024908

Arbiyah, N., Imelda, F. N., \& Oriza, I. D. (2007). Hubungan bersyukur dan subjective well being pada penduduk miskin. Jurnal Psikologi Sosial.

Ariati, J., \& Hyoscyamina, D. E. (2017). Development and initial validation of emotional support and achievement motivation scales as a part of redi-Space assessment. Pertanika Journal of Social Sciences and Humanities.

Chakrawati, F. (2015). Bullying siapa takut. Solo: PT. Tiga Serangkai Pustaka Mandiri.

Citra Kunia putri dan trisna insan Noor, 2011. (2013). Pengaruh Game Kekerasan Terhadap Perilaku Agresif Anak. Analisis Pendapatan Dan Tingkat Kesejahteraan Rumah Tangga Petani, 53(9), 1689-1699.

Hunter, S. C., Durkin, K., Boyle, J., Booth, J. N., \& Rasmussen, S. (2014). Adolescent bullying and sleep difficulties. Europe's Journal of Psychology, 10(4), 740-755.

Kaplan, A. M., \& Haenlein, M. (2012). Social media: back to the roots and back to the future. 
Journal of Systems and Information Technology.

Mahriza, R., Rahmah, M., \& Santi, N. E. (2020). Stop Bullying: Analisis Kesadaran dan Tindakan Preventif Guru pada Anak Pra Sekolah. Jurnal Obsesi : Jurnal Pendidikan Anak Usia Dini, 5(1), 891-899. https://doi.org/10.31004/obsesi.v5i1.739.

Maria, I., \& Novianti, R. (2016). Pengaruh Pola Asuh dan Bullying terhadap Harga Diri (Self Esteem) pada Anak Kelompok B Tk di Kota Pekanbaru Tahun 2016. Jurnal Educhild: Pendidikan Dan Sosial, 6(1), 61-69.

McLeod, S. (2007). Maslow's hierarchy of needs. Simply Psychology, 1(1-18).

Monks, C. P., \& Smith, P. K. (2006). Definitions of bullying: Age differences in understanding of the term, and the role of experience. In British Journal of Developmental Psychology. https://doi.org/10.1348/026151005X82352

Noordjanah, A. (2013). hubungan harga diri dan optimisme dengan motivasi belajar pada siswa man maguwoharjo sleman Yogyakarta. Yogyakarta: Eprinnt. Ums, 10(2), 141-154.

Prabowo, S. H., Fakhruddin, A., \& Rohman, M. (2020). PERAN ORANG TUA DALAM PEMBENTUKAN KARAKTER ANAK DI MASA PANDEMI COVID-19 PERSPEKTIF PENDIDIKAN ISLAM. Al-Tadzkiyyah: Jurnal Pendidikan Islam, 11(2), 191-207.

Rahim, A. (2013). Peranan Orang Tua Terhadap Pendidikan Karakter Remaja Putri Menurut Islam. Al-Ulum, 13(1), 87-102.

Santrock. (2003). Life-Span Development: Perkembangan Masa Hidup. In Erlangga. https://doi.org/10.1109/ciced.2018.8592188.

Santrock, J. W. (2011). Educational Psychology 5th Edition. Educational Psychology. https://doi.org/10.1017/CBO9781107415324.004

Sugiyono. (2015). Metode Penelitian. Metode Penelitian.

Sutriyanti, N. K. (2016). Peningkatan Mutu Pendidikan Karakter Melalui Peran Orang Tua Dalam Keluarga. Jurnal Penjaminan Mutu, 2(1), 14-27.

Wahidin, U. (2017). Pendidikan Karakter Bagi Remaja. Edukasi Islami: Jurnal Pendidikan Islam, 2(03).

Wahyuni, S., \& Nuraini. (2019). Peran Guru PAUD dalam Meningkatkan Perkembangan Moral Anak Usia 5-6 Tahun di Kecamatan Tenayan Raya Kota Pekanbaru. PAUD Lectura: Jurnal Pendidikan Anak Usia Dini. https://doi.org/10.31849/paudlectura.v3i01.3350. 